\title{
Alterations in the Proliferating Compartment of Gastric Mucosa during Helicobacter Pylori Infection: The Putative Role of Epithelial Cells Expressing p27 ${ }^{\mathrm{kip} 1}$
}

Stavros Sougioultzis, M.D., Ph.D., Periklis G. Foukas, M.D., Michalis Tzivras, M.D., Ph.D., Dimitrios Kourtessas, M.D., Vassilis G. Gorgoulis, M.D., Ph.D., Panayiotis Davaris, M.D., Ph.D., Athanasios J. Archimandritis, M.D., Ph.D.

Division of Gastroenterology (SS), Beth Israel Deaconess Medical Center, Harvard Medical School, Boston, Massachusetts; and Department of Pathophysiology (SS, PGF, MT, DK, AJA), Department of Histology and Embryology, Molecular Carcinogenesis Group (VGG), and Department of Pathology (PD), Medical School, University of Athens, Athens, and Department of Histopathology and Molecular Pathology, Locus Medicus Laboratories (PGF), Athens, Greece

The proliferating zone contains stem cells that give rise to all epithelial cells of the gastric mucosa. In the present study, we investigated the turnover of gastric epithelial cells in the proliferating zone of Helicobacter pylori-infected mucosa, with or without intestinal metaplasia, before and after eradication of the microorganism. In addition, we studied the topographical distribution of the cyclin dependent kinase inhibitor $\mathbf{p} 27^{\mathrm{Kip} 1}$, which plays a critical role in cell cycle progression and differentiation programs. Twenty-eight patients (22 male), aged 32-78 years and with dyspeptic symptoms, were endoscoped, and gastric biopsies were obtained from antrum and corpus for histopathological examination and the Campylobacter-like organisms test; eradication therapy was given to infected patients, and all patients were re-endoscoped after 105 \pm 33 days (mean \pm SD). The kinetics of gastric epithelial cells and $\mathbf{p} 27^{\mathrm{Kip} 1}$ status was assessed by means of immunohistochemistry and TUNEL (Tdtmediated dUTP-biotin nick end labeling) assay. Twenty-one (21) of 28 patients were $H$. pylori positive, and 7 were found $H$. pylori negative and served as controls. In antrum, intestinal metaplasia was detected in 7/21 (33.3\%). In H. pylori gastritis, Ki67 expression was found increased in the proliferating

Copyright () 2003 by The United States and Canadian Academy of Pathology, Inc.

VOL. 16, NO. 11, P. 1076, 2003 Printed in the U.S.A.

Date of acceptance: July 21, 2003.

Partly supported by grant 70-3-2945/95ED-1909 PENED/KA from the Ministry of Industry, Energy and Technology, Greece.

Authors SS and PGF contributed equally to this study.

Address reprint requests to: Athanasios J. Archimandritis, M.D., Department of Pathophysiology, Medical School, University of Athens, 75 Mikras Asias Street, Athens 115 27, Greece; fax: 30-210-7462664; e-mail: aarchima@med.uoa.gr.

DOI: 10.1097/01.MP.0000093626.15701.76 zone, compared with normal $(P=.03)$; analogous results were obtained with the other proliferation markers, namely retinoblastoma protein and topoisomerase II $\alpha$. An inverse relationship between proliferation index and atrophy was disclosed $(P=.02)$. $A$ reduction in the proliferation index was observed after eradication, albeit not significant. Apoptotic epithelial cells were found significantly increased $(P$ $<.01)$ in $H$. pylori gastritis, and a significant reduction was observed after eradication $(P<.01)$. In addition, apoptotic index was found to correlate with $H$. pylori density. The topographical study of p27 ${ }^{\text {Kip1 }}$ revealed a p27 $^{\text {kip1 }}$-positive epithelial cell population that resided deep in the proliferating zone; these cells were considered to be stem cells and were found significantly increased in areas with intestinal metaplasia $(P<.05)$; in $H$. pylori gastritis, there was also an increase that did not reach statistical significance. $H$. pylori infection induces apoptosis and increases proliferation in the proliferating zone. The increased cellular turnover, together with the increased number of putative p27 ${ }^{\mathrm{Kip1}}$ positive stem cells in the context of intestinal metaplasia, provides further evidence for the role of $\boldsymbol{H}$. pylori infection in gastric carcinogenesis.

KEY WORDS: Apoptosis, Gastritis, Helicobacter pylori, p27 ${ }^{\text {Kip1 }}$, Proliferation.

Mod Pathol 2003;16(11):1076-1085

The discovery of Helicobacter pylori has revolutionized our thinking on the etiology of peptic ulcer disease (1), MALT lymphoma of the stomach (2), and gastric adenocarcinoma (3).

H. pylori colonization of the human gastric mucosa induces a specific inflammatory tissue reaction described as chronic active gastritis (4), the 
common pathophysiologic denominator of all the above-mentioned diseases. Chronic active gastritis, under the influence of environmental and intrinsic factors, may lead to chronic atrophic gastritis and intestinal metaplasia, which are considered precancerous lesions according to the multistep model of gastric carcinogenesis (5). Although the sequence of events that leads to these lesions is not completely understood, intestinal metaplasia can be viewed as the product of an altered differentiation program that is adopted by the epithelial cells to gain a survival advantage over the original epithelium (6). This modified differentiation program is more likely to be adopted and executed by the gastric epithelial stem cells in an attempt to react to the adverse environment induced by the infection (7). Stem cells are poorly characterized, multipotent cells that are located in the isthmus region of the gastric pit and give rise, through intermediate daughter cells, to the whole epithelial cell population of the gastric mucosa. Divergent behavior of these cells, as expressed mainly by alterations in their turnover rate, probably has a great impact on gastric histopathology (8).

Increased cellular turnover has been linked to cancer development in many epithelial tissues in diseases in which inflammation plays a pivotal role, such as inflammatory bowel disease and colon carcinomas $(9,10)$, autoimmune (Hashimoto's) thyroiditis and papillary thyroid carcinomas (11), chronic pancreatitis and pancreatic cancer $(12,13)$, chronic viral hepatitis, and hepatocellular carcinoma $(14,15)$. Previous studies have shown increased turnover of gastric epithelial cells during $H$. pylori infection; both proliferation (16) and apoptosis (17) were found to be increased in the infected mucosa and connected to the development of atrophy $(18,19)$ and intestinal metaplasia (20). However, detailed analysis of gastric epithelial cell turnover in the discrete gastric pit zones (Zone $1=$ foveolar (surface) epithelium, Zone 2 = isthmus (neck), and Zone 3 = glands) has not been addressed so far.

In an attempt to shed more light on $H$. pylorirelated gastric epithelial alterations, we investigated the turnover of gastric epithelial cells in each discrete gastric pit zone of $H$. pylori-infected mucosa, with or without intestinal metaplasia, before and after eradication of the microorganism. We particularly focused our analysis on the proliferating compartment of the antral mucosa for two reasons: first, it has been demonstrated that $H$. pylori induces more intense and active inflammation in this part of the stomach, and second, the infection has been mainly linked to the development of distal (antral) adenocarcinoma (21). In addition, we studied the topographical distribution of the cyclin dependent kinase inhibitor $\mathrm{p} 27^{\mathrm{Kip} 1}$, which plays a crit- ical role in cell cycle progression and differentiation programs.

\section{MATERIALS AND METHODS}

\section{Study Design}

A total of 130 patients with dyspeptic symptoms were screened for possible enrollment in this prospective study, and 80 of them were found to be eligible. We finally studied gastric mucosa tissue specimens from 28 patients (22 males, 6 females), aged between 32 and 78 years $(53.3 \pm 13.9$ years (mean $\pm \mathrm{SD}$ ), who attended for a follow-up endoscopy approximately 3 months after their initial visit.

Patients were included if they were tested $H$. pylori positive or negative by both used methods, namely the CLO (Campylobacter-like organisms) test and histologic identification of the microorganism. Patients with peptic ulcer disease who tested $H$. pylori negative and those who reported any eradication therapy or any previous gastric surgery were excluded. Patients who reported any antiulcer therapy or any antibiotic or bismuth salt therapy during the previous 4 weeks were also excluded. Nonsteroid anti-inflammatory drug or aspirin users, patients on corticosteroids or any immunosuppressive therapy, pregnant women, women of reproductive age who did not take efficient contraception, and patients suffering from severe disease of any kind were not included in the study.

The study was performed in accordance with the declaration of Helsinki. The protocol was fully explained to the patients, and consent was obtained from all of them.

All patients underwent upper gastrointestinal endoscopy, and six biopsies were taken as follows: two biopsies, one from the antrum and one from the corpus for CLO test; two from the antrum (anterior and posterior wall); and two from the corpus (anterior and posterior wall) that were immediately fixed in formalin $10 \%$ for histologic and immunohistochemical evaluation. The patients who tested positive for $H$. pylori were given triple eradication therapy consisting of omeprazole $(20 \mathrm{mg}$ bid) plus amoxicillin ( $1 \mathrm{~g}$ bid) plus clarithromycin $(500 \mathrm{mg}$ bid) for 7 days. Omeprazole (20 mg qid) was given for an additional 3 weeks after eradication therapy. No anti-ulcer therapy was given to the patients who tested negative for $H$. pylori. The second endoscopy was performed on all patients $105 \pm 33$ days after the initial examination. Tissue specimens were obtained again and processed in the same way. All biopsy specimens from the initial and follow-up endoscopies were assessed simultaneously for the immunohistochemical parameters to avoid dis- 
crepancies in evaluation due to different laboratory conditions.

Proliferation was assessed with three cell cyclespecific markers, namely Ki67, retinoblastoma protein $(\mathrm{pRb})$, and topoisomerase $\mathrm{II} \alpha$, to better define the width of the proliferation zone, whereas apoptosis was evaluated with the TUNEL assay. After evaluating gastric epithelial cell turnover, we investigated $\mathrm{p} 27^{\mathrm{Kip} 1}$ topographical distribution.

\section{Histopathology}

Formalin-fixed, paraffin-embedded tissue samples were routinely cut at 3-4 $\mu \mathrm{m}$ and stained with hematoxylin and eosin, Alcian blue $(\mathrm{pH}=2.5)$, and Giemsa. Only well-oriented mucosal specimens were evaluated, and specimens were classified independently by three pathologists (PGF, VGG, and PD) who were unaware of the corresponding clinical and endoscopic findings. Re-examination and consensus resolved differences in their independent reports.

Gastritis parameters (chronic inflammation, activity, intestinal metaplasia, gland atrophy, and $H$. pylori density) were graded semiquantitatively on a scale of 0 to $3(0=$ absent, $1=$ mild, $2=$ moderate, 3 = severe), using a standard visual analogue scale, according to previously reported criteria (updated Sydney System) (22).

\section{Immunohistochemistry}

\section{Antibodies}

For immunohistochemical analysis the following antibodies were used:

Anti-Ki67 (mouse monoclonal, IgG1, Clone MIB-1; Oncogene Science, 1/50 dilution), anti-pRb (mouse monoclonal, IgG1, Clone LM95.1; Calbiochem, 1/50 dilution), anti-topoisomerase IIa (mouse monoclonal, IgG1, Clone SWT3D1; DAKO, $1 / 250$ dilution), and anti-p27 ${ }^{\mathrm{Kip} 1}$ (mouse monoclonal, IgG1, Clone SX53G8; DAKO, 1/100 dilution).

Immunohistochemistry was performed on paraffin sections on poly-L-lysine (Sigma Chemical Co., St. Louis, MO)-pretreated slides, by applying the indirect streptavidin-biotin-alkaline phosphatase method, as we have described elsewhere (23). Unmasking of the studied proteins was carried out with the heat-mediated antigen retrieval method (microwave treatment in citrate buffer at $\mathrm{pH} 6$ for 20 minutes), before blocking serum application.

For negative control, the same immunohistochemical procedure was followed, replacing the primary antibody either with Tris buffered saline or with an irrelevant antibody of the same animal and isotype.

\section{Evaluation and quantification}

For scoring, only nuclear immunopositivity for all the tested proteins was considered as evidence of expression of the molecule. There was some variation in nuclear staining intensity, and therefore all positively stained nuclei, regardless of color intensity, were scored as positive. For counting, the gastric mucosa was divided into three zones: Zone 1, surface and upper one third of gastric pit; Zone 2, the other two thirds of gastric pit; and Zone 3, gastric glands. In each zone, $\geq 500$ cells were counted; the number of positively stained nuclei was expressed as the percentage of positive nuclei to the total number of counted nuclei and was defined as labeling index. From this point onward, the Ki-67 labeling index will be referred to as the proliferation index.

Inter- and intraobserver differences were $<5 \%$, and only in some discordant cases, re-evaluation was performed with a multiheaded microscope.

\section{Tdt-Mediated dUTP-Biotin Nick End Labeling Method}

Double-strand DNA breaks were detected by TUNEL according to Gavrieli et al (24). Briefly, $5-\mu \mathrm{m}$ paraffin sections were mounted on poly-Llysine-coated slides, dewaxed, and rehydrated in alcohol gradient. Pretreatment was carried out by incubating the sections with Proteinase K (Sigma, Greece; $20 \mu \mathrm{g} / \mathrm{mL}$ ) for 15 minutes at $37^{\circ} \mathrm{C}$. The labeling step was performed with TdT (terminal deoxytransferase; $15 \mathrm{U}$ per slide; New England Biolabs, Bioline, Greece) for 1 hour at $37^{\circ} \mathrm{C}$ in $25 \mathrm{~mm}$ Tris- $\mathrm{HCl}, \mathrm{pH} 7.2,200 \mathrm{~mm}$ potassium cocodylate, $0.25 \mathrm{~mm} \mathrm{CoCl}, 250 \mathrm{mg} / \mathrm{mL}$ of BSA, and $24 \mu \mathrm{M}$ biotin-dATP (Life Technologies, AntiSel, Greece). Reaction was stopped by rinsing the sections in 20 mM EDTA. This was followed by 30 minutes' incubation in StreptABComplex/AP (DAKO, Kalifronas, Greece). For color development, we used Fast Red (Sigma) as chromogen and hematoxylin Mayer as counterstain.

Human tonsil tissue and tissue sections incubated with DNAase I before treatment with TdT were used as positive controls; sections incubated in TdT buffer omitting the terminal deoxytransferase served as negative controls. Apoptotic events in germinal centers of secondary lymphoid follicles, in some cases of gastritis, were also used as internal positive control.

\section{Evaluation and quantification}

Cells were considered to undergo apoptosis when apoptotic bodies' staining, without cytoplasmic background, was observed. As in the evaluation and quantification of immunohistochemical results, ap- 
optotic index was calculated per zone, and the results are expressed as the percentage of TUNELpositive apoptotic bodies to the total counted cells ( $\geq 500$ were evaluated in each zone). Two TUNELpositive apoptotic bodies were considered as belonging to different cells if their distance was more than the diameter of an epithelial cell. Slide examination was performed by three independent observers (PGF, VGG, and PD), and interobserver variability was minimal $(<5 \%)$.

\section{Statistical Analysis}

The nonparametric Wilcoxon tests for paired and unpaired measurements and Spearman's rank correlation coefficient test were used as appropriate. In addition, the Kruskal-Wallis test was used for intergroup comparisons (more than two groups), followed by Dunn's multiple comparisons test (computer program: Graphpad Prism, Version 2.01; Graphpad Software Inc. CA).

\section{RESULTS}

Of the 28 patients, 21 were $H$. pylori positive. Of them, 17 had duodenal ulcer; 3 , duodenal and gastric ulcer; and 1 had only gastric ulcer. Seven patients were $H$. pylori negative and served as controls. Patients and controls did not differ in age. $H$. pylori was successfully eradicated in $15 / 21$ patients.

\section{Histopathology Findings}

Infected patients showed significantly greater chronic inflammation and $H$. pylori density in the gastric antrum than corpus (Wilcoxon: $P=.008, P$ $=.01$, respectively). Activity was also more pronounced in the antrum but did not reach statistical significance in this group of patients $(P=.06)$. However, significant correlation between the activity of gastritis and $H$. pylori density was found (Spearman, antrum: $P=.008$, corpus: $P=.0006$ ).

In the antrum, atrophy was detected in $8 / 21$ $(38.1 \%$, all cases were graded as mild) and intestinal metaplasia in $7 / 21(33.3 \%)$. In the corpus, only two patients had mild atrophy, and one had intestinal metaplasia.

After eradication, significant reduction of chronic inflammation both in antrum and corpus was observed (Wilcoxon: $P<.001, P<.001$, respectively). Activity was also significantly decreased (Wilcoxon: antrum, $P=.002$; corpus, no activity after eradication). No changes in prevalence of atrophy and intestinal metaplasia were observed during the follow-up period.

\section{Gastric Epithelial Cell Kinetics \\ Proliferation status}

In normal mucosa, Ki67-positive cells were restricted in Zone 2 (Table 1) without any stained nucleus in Zones 1 and 3. In $H$. pylori-inflamed mucosa, there is a significant increase of positively stained nuclei in Zone 2 (Wilcoxon, $P=.03$ ) with an increase in the width of the zone, which is defined by Ki67-positive cells, due to an upward extension of the proliferation compartment (Fig. 1A). After eradication, the proliferation index was reduced but not significantly (Wilcoxon, $P=.09$; Fig. 1B). The proliferation index in Zone 2, in antrum, was found inversely related to atrophy; this was confirmed by both proliferation markers used, namely Ki-67 (Wilcoxon, $P=.02$ ) and pRb (Wilcoxon, $P=$ .067; Fig. 2). No correlation with the other gastritis parameters was disclosed.

In normal mucosa, $\mathrm{pRb}(+)$ cells were located in Zone 2; the staining was almost continuous, starting from the lower border of Zone 2 and upwards. Furthermore, a significant correlation between the pRb- and Ki67-labeling indices was found (Spearman, $r_{\mathrm{s}}=0.81, P=.01$ ). In $H$. pylori gastritis, the area of pRb-stained cells was enlarged toward the surface; the number of pRb-positive cells was also markedly increased. After eradication of the microorganism, a reduction, although not a statistically significant one, was observed (Table 1).

To further investigate the extent of the proliferation zone in gastric mucosa and better verify its borders, we studied the expression of topo-

TABLE 1. Measurements Refer to the Proliferation Compartment (zone 2) of the Antrum: Gastric Epithelial Cell Kinetics (PI\% and $\mathrm{Al} \%$ ) and the Percentage (LI\%) of pRb and p27 ${ }^{\mathrm{Kip} 1}$ Positive Cells in Normal and Helicobacter pyloriInfected Mucosa, Before and After Eradication of the Microorganism

\begin{tabular}{|c|c|c|c|c|}
\hline & Ki67 (PI\%) & TUNEL (AI\%) & pRb (LI\%) & $\begin{array}{c}\text { p27 } \\
\text { (LI\%) }\end{array}$ \\
\hline Normal mucosa & $5.16 \pm 0.79$ & $0.01 \pm 0.04$ & $8.99 \pm 2.6$ & $0.82 \pm 0.03$ \\
\hline H. pylori gastritis & $13.78 \pm 6.5$ & $0.86 \pm 0.745$ & $31.02 \pm 12.7$ & $1.68 \pm 0.97$ \\
\hline \multirow[t]{3}{*}{ After eradication } & $8.74 \pm 5.12$ & $0.185 \pm 0.221$ & $22.02 \pm 14.57$ & $0.99 \pm 0.58$ \\
\hline & $\mathrm{p}_{\mathrm{A}}^{*}=0.03$ & $\mathrm{p}_{\mathrm{A}}=<0.01$ & $\mathrm{p}_{\mathrm{A}}=<0.01$ & $\mathrm{p}_{\mathrm{A}}=\mathrm{NS}$ \\
\hline & $\mathrm{p}_{\mathrm{B}}^{* *}=\mathrm{NS}$ & $\mathrm{p}_{\mathrm{B}}=<0.01$ & $\mathrm{p}_{\mathrm{B}}=\mathrm{NS}$ & $\mathrm{p}_{\mathrm{B}}=\mathrm{NS}$ \\
\hline
\end{tabular}

\footnotetext{
${ }^{*} \mathrm{p}_{\mathrm{A}}$ values refer to comparisons between normal and Helicobacter pylori-infected mucosa.

${ }^{* *} \mathrm{p}_{\mathrm{B}}$ values refer to comparisons in Helicobacter pylori-infected patients before and after eradication.

PI, proliferation index; AI, apoptotic index; LI, labeling index; NS, not significant.
} 

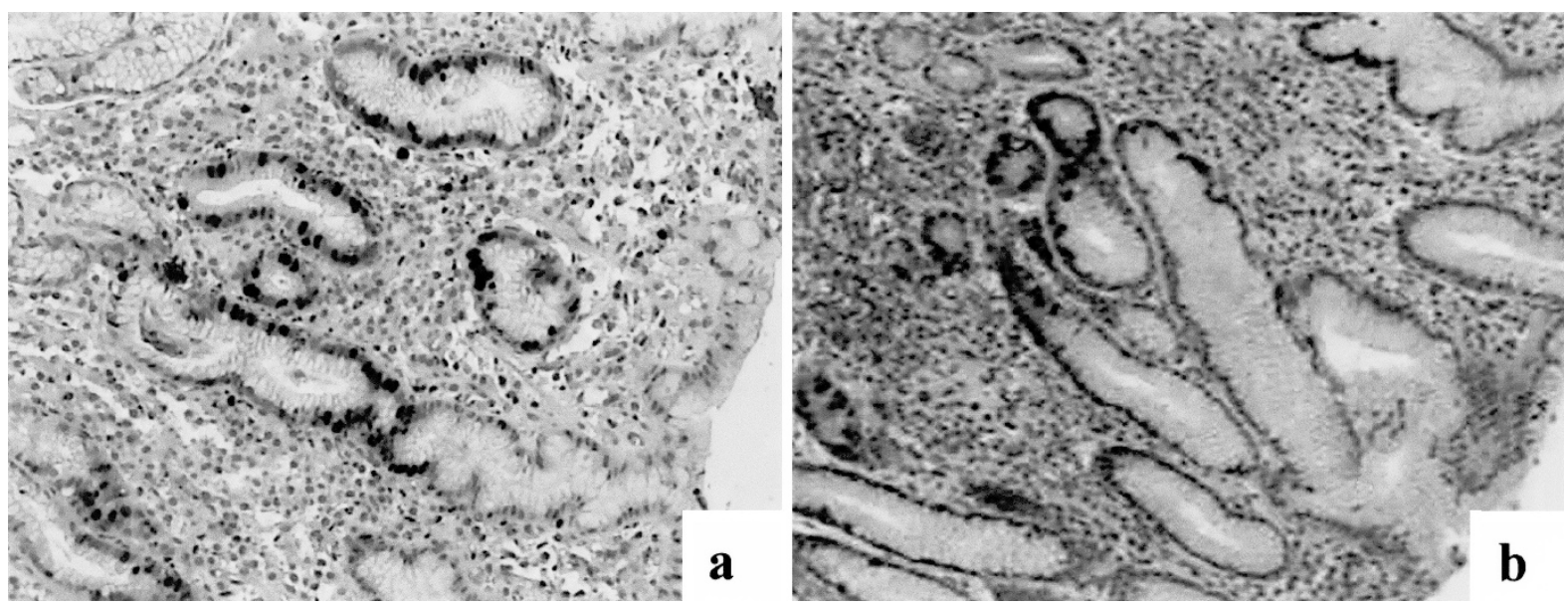

FIGURE 1. Ki67 expression in Helicobacter pylori-infected mucosa (A) and after eradication of the microorganism (B; 100×; from the same patient).

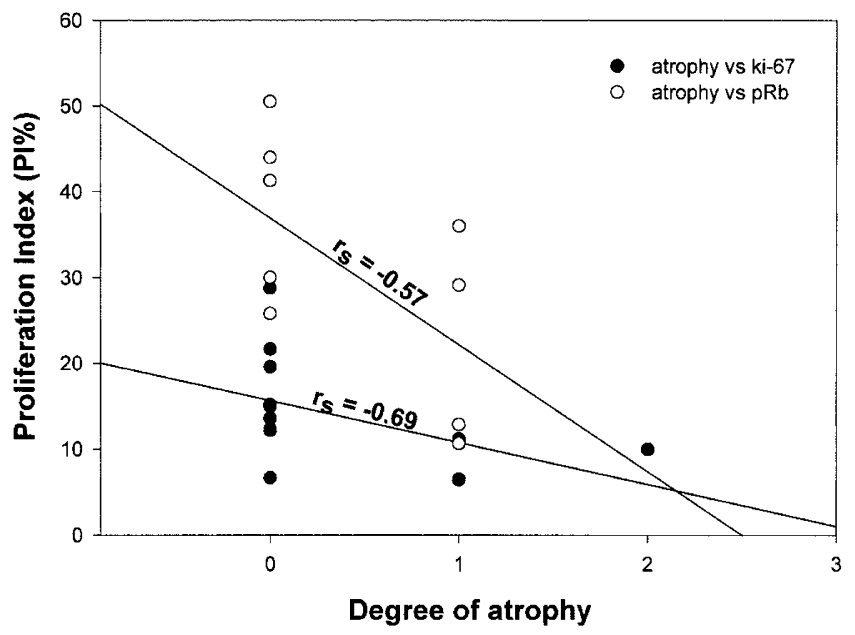

FIGURE 2. An inverse relationship between atrophy and the proliferation index of the antral proliferating zone was observed. As shown, Ki-67 was found significantly reduced in the atrophic mucosa (*Wilcoxon, $P=.02$ ); pRb had the same trend, although the difference in staining between nonatrophic and atrophic mucosa did not reach statistical significance $(* *$ Wilcoxon, $P=.067)$. Results are expressed as mean \pm SE.

isomerase II $\alpha$, a clear S to G2/M phase marker, in some of the biopsies. The width of the topoisomerase II $\alpha$-positive compartment was similar to that of the Ki67-positive compartment, although fewer cells were stained positive with the topoisomerase II $\alpha$.

\section{Apoptotic status}

In normal mucosa, TUNEL-positive apoptotic bodies were observed only in superficial cells (Zone 1), and no apoptosis was detected in foveolar and glandular epithelium (Zones 2 and 3). In $H$. pylori gastritis, the apoptotic index was increased in Zone 1, both in antrum (Wilcoxon, $P=$ .0005) and corpus compared with normal; however, in corpus, the increase was not statistically significant (Wilcoxon, $P=.15$ ). Apoptosis was also observed in Zone 2 and correlated significantly with $H$. pylori density, both in antrum and corpus (Fig. 3). After H. pylori eradication, apoptotic index was reduced in Zone 2 (Wilcoxon; antrum: $P=.002$, corpus: $P=.03$ ), and the degree of apoptosis approached that of normal mucosa (Table 1).

\section{p27 $7^{\text {Kip1 }}$ expression}

In normal mucosa, nuclear p2 $7^{\mathrm{Kip} 1}$ immunoreactivity was restricted in two discrete epithelial cell populations. One population that was invariably $\mathrm{p} 27^{\mathrm{Kip} 1}$ positive was the terminally differentiated cells in the superficial epithelium (Zone 1). The staining intensity was weak in these cells compared with in few $\mathrm{p} 27^{\mathrm{Kip} 1}$-positive mature lymphocytes of the lamina propria, which served as internal positive control. The second $\mathrm{p} 27^{\mathrm{Kip} 1}$ positive population was localized in the most

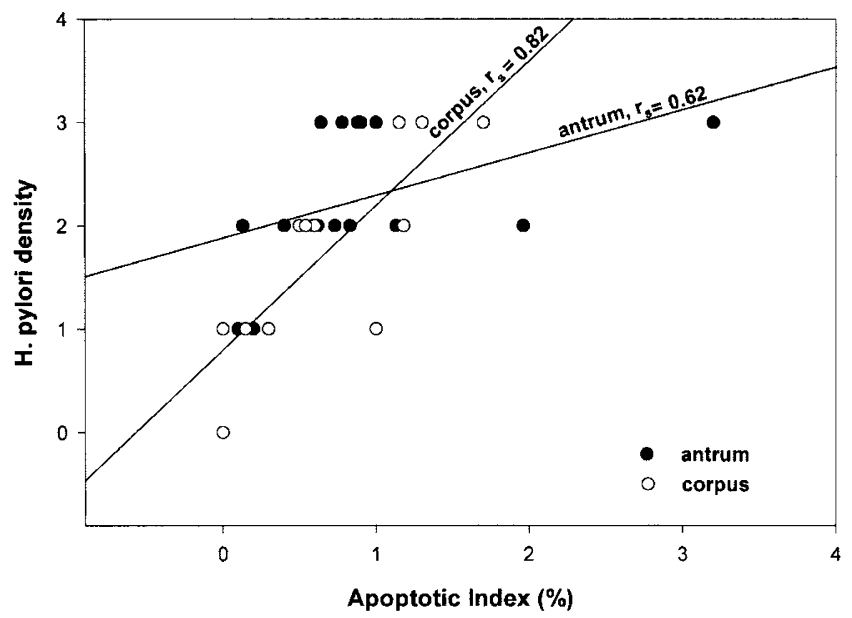

FIGURE 3. Apoptotic index in the proliferation compartment was found to be significantly related to Helicobacter pylori density; this was confirmed in both antral (Kruskal-Wallis, $P=.002$; Dunn's, $P=.01$ ) and corpus (Kruskal-Wallis, $P=.02$; Dunn's, $P<.05$ ) mucosa. 
deep portion (neck zone) of Zone 2, confined in the area of Ki67-positive cells (proliferating zone). The staining was more intense than in superficial cells and equal to lamina propria lymphocytes. No staining was observed by glandular (Zone 3) epithelial cells.

In H. pylori gastritis, there was an increase, but not one statistically significant, of $\mathrm{p} 27^{\mathrm{Kip} 1}$ positive cells in Zone 2 (Fig. 4A). No differences were disclosed in the staining pattern of Zones 1 and 3. After H. pylori eradication, p2 ${ }^{\mathrm{Kip} 1}$ expression in nonmetaplastic mucosa looks quantitatively and spatially almost like normal mucosa (Fig. 4B), restricted in the the most deep area of
Ki67-positive proliferation compartment. Interestingly, in gastric pits with intestinal metaplasia, a significant increase of $\mathrm{p} 27^{\mathrm{Kip} 1}$-positive cells in the proliferating zone was observed (Fig. 4C, C*, $\mathrm{D}$, and $\mathrm{D}^{*}$ ) as compared with either normal (Wilcoxon, $P<.05$ ) or $H$. pylori-infected mucosa without intestinal metaplasia (Wilcoxon, $P<.05$ ). Moreover, the epithelial cells in the proliferating zone exhibited a mutually exclusive pattern of staining between Ki-67 and p27 ${ }^{\mathrm{Kip} 1}$, both in $H$. pylori gastritis and metaplastic mucosa (compare Fig. $4 \mathrm{C}^{*}$ and $\mathrm{D}^{*}$ ). In areas of intestinal metaplasia, the staining pattern remained the same during the follow-up period.

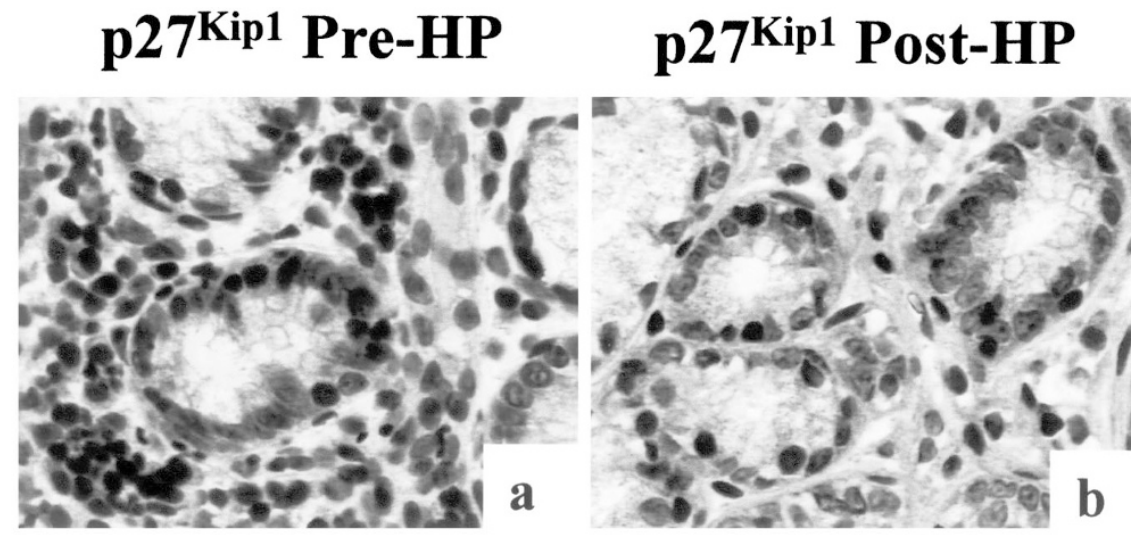

\section{p27 ${ }^{\text {Kip1 }}$ IM}

Ki67 IM
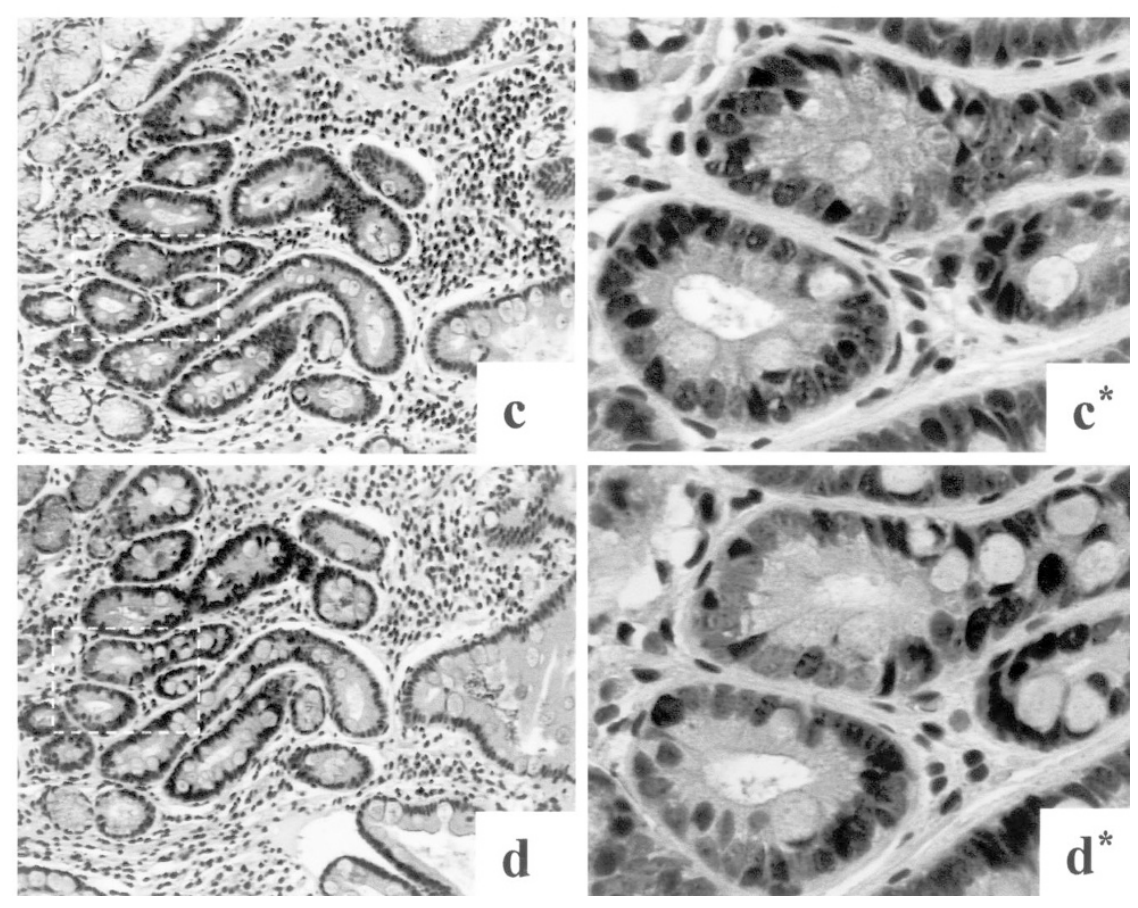

FIGURE 4. p2 $7^{\mathrm{Kip} 1}$ expression in gastric mucosa. A, p2 $7^{\mathrm{Kip} 1}$ expression in the neck region epithelial cells in a case of Helicobacter pylori gastritis

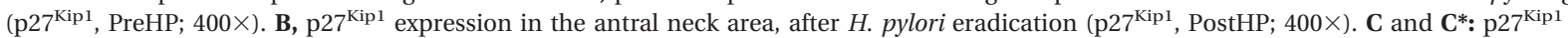
expression in a case with intestinal metaplasia (p27 ${ }^{\text {Kip1 }}$, IM; C, 100×; C*, 400×). D and $\mathbf{D}^{*}$ : Ki67 expression in serial sections of the same case with intestinal metaplasia (Ki67, IM; D, 100×; D*, 400×). (The dotted squares in $\mathbf{C}$ and $\mathbf{D}$ denote the area that is amplified in $\mathbf{C}^{*}$ and $\mathbf{D}^{*}$, respectively). Note the mutually exclusive staining pattern for $\mathrm{p} 27^{\mathrm{Kip} 1}$ and Ki67 of metaplastic epithelial cells in the most deep epithelial compartments, comparing $\mathbf{C}^{*}$ and $\mathbf{D}^{*}$. 


\section{DISCUSSION}

We report here that $H$. pylori infection increases the gastric epithelial cell turnover in the proliferation compartment of the gastric mucosa as well as the population of $\mathrm{p} 27^{\mathrm{Kip} 1}$-positive epithelial cells in the proliferation compartment, in areas of $H$. pylo$r i$-related intestinal metaplasia.

We observed an increase in epithelial cell apoptosis in $H$. pylori gastritis that likely represents a cellular self-defense mechanism (25) against the hostile milieu generated by the infection. It seems to be the result of $H$. pylori-epithelial interactions because we found a significant relationship between the apoptotic index and the density of $H$. pylori, both in antrum and corpus (Fig. 3). This finding, together with the observed significant reduction of apoptosis in gastric epithelial cells after eradication of the microorganism, suggests that the bacterium itself play an important role in inducing apoptosis in gastric mucosa. Several in vitro studies using different $H$. pylori strains have also shown that bacterial factors can directly mediate epithelial apoptosis (26-28). Moreover, in vivo studies propose that there is no increase in apoptosis in gastritis of different etiology than $H$. pylori infection (16), suggesting that inflammation per se does not cause apoptosis in gastric mucosa.

On the other hand, proliferation, although increased during the infection (Table 1), was not found to be statistically decreased after eradication, in agreement with a recent study by El-Zimaity $e t$ al. (29), who reported that hyperproliferation of gastric mucosa persists for 3 years after $H$. pylori eradication. Although the reason for the sustained hyperproliferation is not clear, it may represent a counterbalance to the increased apoptotic rate, as suggested by our finding of the inverse relationship between the proliferation index in the proliferating zone and atrophy (Fig. 2). Nevertheless, we must admit the limitations of this analysis that are caused by the known difficulties in estimating gastric atrophy, especially in the context of inflammation (30).

For assessment of proliferation, we performed immunohistochemistry with three different antibodies, namely anti-Ki67, anti-pRb, and antitopoisomerase II $\alpha$ (31), and we found that all three antibodies are reliable in estimating proliferation in the gastric mucosa.

Given that gastric epithelial cells' turnover is associated with chronic infection and that the latter induces intestinal metaplasia (32), a possible alteration in the gastric epithelial cell differentiation and maturation program may exist in $H$. pylori gastritis. One popular theory suggests that intestinal metaplasia may be the result of an altered differentiation program adopted by stem cells to survive in a hos- tile environment (6). This is probably achieved through modifications in their gene expression program that favor differentiation along an alternative, but close to "normal" route $(6,7)$. Based on evidence showing the important function of p27 ${ }^{\mathrm{Kip} 1}$ in many cellular processes, including proliferation, differentiation, and apoptosis $(33,34)$, we looked for $\mathrm{p} 27^{\mathrm{Kip} 1}$ expression in an attempt to investigate the role of this molecule in $H$. pylori-gastritis and in H. pylori-associated intestinal metaplasia. Previous studies have shown that loss of $\mathrm{p} 27^{\mathrm{Kip} 1}$ expression is associated with aggressive tumor behavior in gastric cancer (35) as well as other epithelial malignancies $(36,37)$.

We found that expression of $\mathrm{p} 27^{\mathrm{Kip} 1}$ was faint on surface epithelial cells and quantitatively invariable between normal and inflamed mucosa; it seemed to be independent of the underlying histologic lesions. This is in agreement with the role of $\mathrm{p} 27^{\mathrm{Kip} 1}$ in tissue development and expression by senescent, terminally differentiated cells $(38,39)$. In the proliferation compartment, we defined two cellular populations: one that is $\mathrm{p} 27^{\mathrm{Kip} 1}$ negative and one that is $\mathrm{p} 27^{\mathrm{Kip} 1}$ positive. The phenotype of these cells was similar, but they differed in topography. The p2 $7^{\text {Kip1 }}$-positive epithelial cells were located in the deepest area (neck zone) of Zone 2, and their number was found increased, although not significantly, in inflamed mucosa (Fig. 4A). Moreover, we observed a mutually exclusive staining pattern between p2 $7^{\text {Kipl }}$ and Ki67 on those cells. Based on the topographical distribution of $\mathrm{p} 27^{\mathrm{Kip} 1}$ in our study and other reports of its expression in various tissues (40-42), we speculate that the $\mathrm{p} 27^{\mathrm{Kip} 1}$-positive population in the neck area represents stem cells, whereas the more superficial Ki67-positive, p2 $7^{\text {Kip1 }}$ negative cells belong to transiently proliferating cells. The constitutive expression of a universal cyclin-dependent kinase inhibitor, like p2 $7^{\mathrm{Kip} 1}$, by neck zone cells is compatible with the main property of stem cells, which is long cell cycle periods in order to control replication quality. Walsh et al. (41) have reached a similar conclusion in inflamed colonic mucosa, in which they observed increased p2 $7^{\text {Kip } 1}$ immunopositivity in the lowest on third of crypts, suggesting that enhanced expression of p2 $7^{\text {Kip } 1}$ by this putative stem cell compartment represents a protective reaction. In accordance with the above observations and suggestions are also the findings of De Marzo and coworkers in the prostate (42).

Although we did not investigate p27 ${ }^{\mathrm{Kip} 1}$ expression in gastritis of other etiologies, we believe that our findings are specific to $H$. pylori infection based on evidence from two recent reports. The first, a study on a transgenic mouse model, has demonstrated that a main effect of $H$. pylori infection was the amplification of the presumptive gastric epithe- 
lial stem cells and their immediate committed daughters (43). The second, an in vitro study (44), suggests that $H$. pylori secrete a soluble factor or factors of approximately $40 \mathrm{kDa}$ that up-regulate p2 $7^{\text {Kip } 1}$ expression in epithelial cells. Those investigators speculate that because bacterial-cell attachment is not required, the factor or factors may exert their effects in noncolonized distant epithelial cells, such as the cells in the proliferating compartment.

An interesting finding of our study was the demonstration of an increased number of p27 $7^{\mathrm{Kip} 1}$ positive cells in areas of intestinal metaplasia. In the absence of a reliable marker for the secure identification of stem cells, one may argue that the observed increase of $\mathrm{p} 27^{\mathrm{Kip} 1}$-positive cells reflects induction of expression of the molecule by transiently proliferating cells. We believe, based on topography (schematic representation in Fig. 5) and the mutually exclusive pattern of staining between p27 ${ }^{\text {Kip } 1}$ and Ki67 in serial sections (Fig. 4C*, D*), that they represent an increase in the number of stem cells that probably accounts for the known enhanced proliferative capacity of the metaplastic epithelium (45). Alternatively, increased expression of $\mathrm{p} 27^{\mathrm{Kip} 1}$ may contribute to the altered differenti- ation program engaged by epithelial cells in the area of metaplasia.

To the best of our knowledge, only two reports have studied p $27^{\mathrm{Kip} 1}$ expression in normal mucosa and $H$. pylori gastritis. Our results are not fully compatible with the observations reported by Shirin et al. (46), who found decreased expression of p $27^{\text {Kipl }}$ in the infected mucosa compared with normal. Except from the different antibody used in that study, we can offer two possible explanations for this discrepancy: first, Shirin et al. assessed the staining semiquantitatively, and second, they did not perform detailed analysis by dividing the epithelial compartment into zones as we did in our study. In another recently published study (47), p2 $7^{\text {Kip } 1}$ was also found to be decreased in H. pylori gastritis and in areas of intestinal metaplasia, compared with normal. However, in this study, a polyclonal antibody was used, both nuclear and cytoplasmic staining were counted as expression, and the analysis was not focused in the proliferating compartment.

Taken together (Fig. 5), our data suggest that $H$. pylori induces apoptosis in epithelial cells in vivo. Hyperproliferation is probably a compensatory re- normal

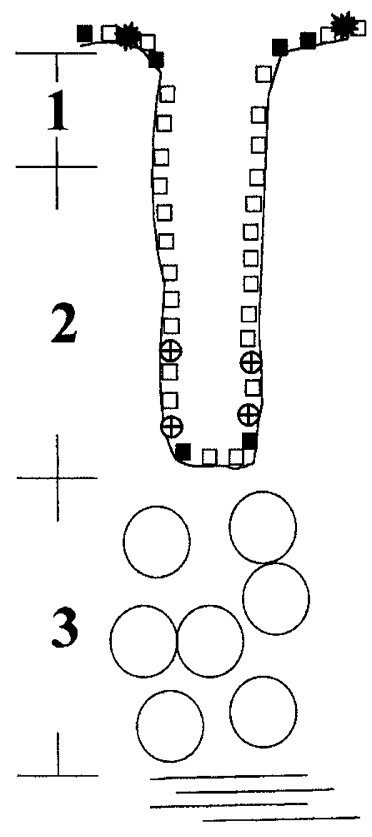

\section{$\mathbf{H P}(+)$ gastritis}

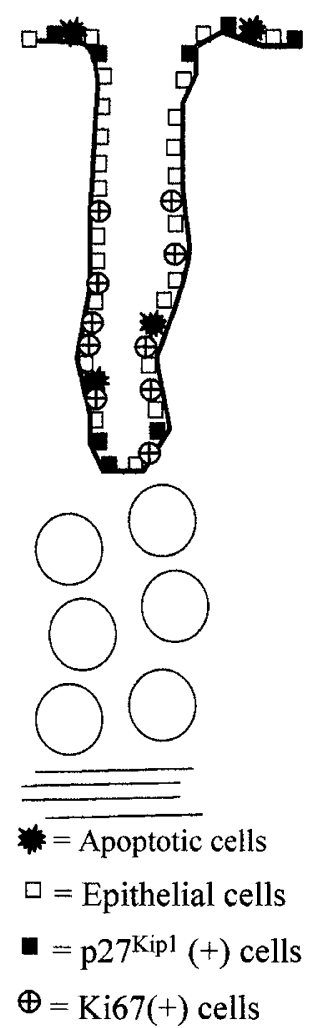

Intestinal metaplasia

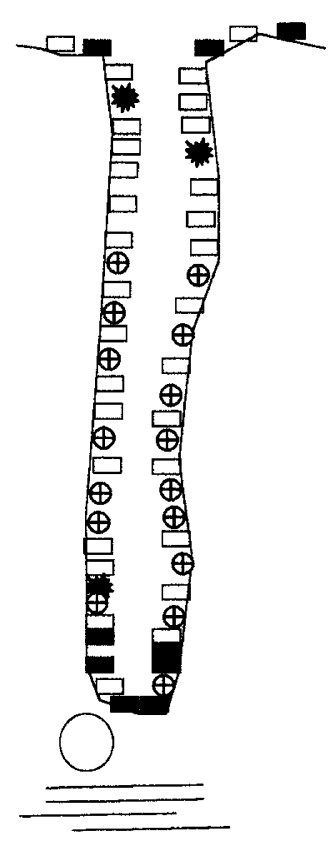

FIGURE 5. Schematic representation of the observed staining pattern for TUNEL assay, Ki67 and p27 Kip1 antibodies in normal mucosa, $H$. pylori gastritis, and intestinal metaplasia. $1=$ Zone 1 (surface epithelium and upper one third of the gastric pit); $2=$ Zone 2 (proliferating compartment, the remaining two thirds of gastric pit); 3 = Zone 3 (gastric glands). 
sponse of the mucosa, and its relative failure may lead to gastric atrophy. Furthermore, we propose that $\mathrm{p} 27^{\mathrm{Kip} 1}$ cells in the proliferation compartment are putative stem cells, and the increased number of these cells in $H$. pylori-associated intestinal metaplasia is in accordance with its characterization as a precancerous lesion. We believe that the metaplastic epithelium, occupied by an increased number of progenitors, is more susceptible to noxious environmental stimuli and that the overall chance of mutation acquisition with oncogenic potential is amplified.

Acknowledgments: The authors thank Prof. H.M. Moutsopoulos, Head of the Department of Pathophysiology, University of Athens, Medical School, for his suggestions and comments. They also thank Professor D.A. Antonioli at Beth Israel Deaconess Medical Center, Harvard Medical School, for critical review of the manuscript. The authors are grateful to Ms. Maria Koi and Ms. Peggie Andriopoulou for their valuable technical assistance and to Ms. Pinelopi Tsiara, who produced all the photomicrographs in this article.

\section{REFERENCES}

1. Kuipers EJ, Thijs JC, Festen HP. The prevalence of Helicobacter pylori in peptic ulcer disease. Aliment Pharmacol Ther 1995;9 (Suppl 2):59-69.

2. Wotherspoon AC, Ortiz-Hidalgo C, Falzon MR, Isaacson PG. Helicobacter pylori-associated gastritis and primary B-cell gastric lymphoma. Lancet 1991;338:1175-6.

3. Huang JQ, Sridhar S, Chen Y, Hunt RH. Meta-analysis of the relationship between Helicobacter pylori seropositivity and gastric cancer. Gastroenterology 1998;114:1169-79.

4. Hui PK, Chan WY, Cheung PS, Chan JK, Ng CS. Pathologic changes of gastric mucosa colonized by Helicobacter pylori. Hum Pathol 1992;23:548-56.

5. Correa P. Human gastric carcinogenesis: a multistep and multifactorial process-First American Cancer Society Award Lecture on Cancer Epidemiology and Prevention. Cancer Res 1992;52:6735-40.

6. Dixon MF. Histological responses to Helicobacter pylori infection: gastritis, atrophy and preneoplasia. Baillieres Clin Gastroenterol 1995;9:467-86.

7. Slack JM. Epithelial metaplasia and the second anatomy. Lancet 1986;2:268-71.

8. Karam SM. New insights into the stem cells and the precursors of the gastric epithelium. Nutrition 1995;11:607-13.

9. Ekbom A, Helmick C, Zack M, Adami HO. Ulcerative colitis and colorectal cancer. A population-based study. N Engl J Med 1990;323:1228-33.

10. Loeb KR, Loeb LA. Genetic instability and the mutator phenotype. Studies in ulcerative colitis. Am J Pathol 1999;154: 1621-6.

11. Okayasu I, Fujiwara M, Hara Y, Tanaka Y, Rose NR. Association of chronic lymphocytic thyroiditis and thyroid papillary carcinoma. A study of surgical cases among Japanese, and white and African Americans. Cancer 1995;76:2312-8.

12. Ekbom A, McLaughlin JK, Karlsson BM, Nyren O, Gridley G, Adami HO, et al. Pancreatitis and pancreatic cancer: a population-based study. J Natl Cancer Inst 1994;86:625-7.
13. Lowenfels AB, Maisonneuve P, Cavallini G, Ammann RW, Lankisch PG, Andersen JR, et al. Pancreatitis and the risk of pancreatic cancer. International Pancreatitis Study Group. N Engl J Med 1993;328:1433-7.

14. Robinson WS. Molecular events in the pathogenesis of hepadnavirus-associated hepatocellular carcinoma. Annu Rev Med 1994;45:297-323.

15. Tsukuma H, Hiyama T, Tanaka S, Nakao M, Yabuuchi T, Kitamura T, et al. Risk factors for hepatocellular carcinoma among patients with chronic liver disease. N Engl J Med 1993;328:1797-801.

16. Jones NL, Shannon PT, Cutz E, Yeger H, Sherman PM. Increase in proliferation and apoptosis of gastric epithelial cells early in the natural history of Helicobacter pylori infection. Am J Pathol 1997;151:1695-703.

17. Moss SF, Calam J, Agarwal B, Wang S, Holt PR. Induction of gastric epithelial apoptosis by Helicobacter pylori. Gut 1996; 38:498-501.

18. Moss SF, Valle J, Abdalla AM, Wang S, Siurala M, Sipponen P. Gastric cellular turnover and the development of atrophy after 31 years of follow-up: a case-control study. Am J Gastroenterol 1999;94:2109-14.

19. Vorobjova T, Maaroos HI, Sipponen P, Villako K, Uibo R. Apoptosis in different compartments of antrum and corpus mucosa in chronic Helicobacter pylori gastritis. An 18-year follow-up study. Scand J Gastroenterol 2001;36:136-43.

20. Scotiniotis IA, Rokkas T, Furth EE, Rigas B, Shiff SJ. Altered gastric epithelial cell kinetics in Helicobacter pyloriassociated intestinal metaplasia: implications for gastric carcinogenesis. Int J Cancer 2000;85:192-200.

21. Talley NJ, Zinsmeister AR, Weaver A, DiMagno EP, Carpenter HA, Perez-Perez GI, et al. Gastric adenocarcinoma and Helicobacter pylori infection. J Natl Cancer Inst 1991;83:1734-9.

22. Dixon MF, Genta RM, Yardley JH, Correa P. Classification and grading of gastritis. The updated Sydney System. International Workshop on the Histopathology of Gastritis, Houston 1994. Am J Surg Pathol 1996:20:1161-81.

23. Archimandritis A, Sougioultzis S, Foukas PG, Tzivras M, Davaris P, Moutsopoulos HM. Expression of HLA-DR, costimulatory molecules B7-1, B7-2, intercellular adhesion molecule-1 (ICAM-1) and Fas ligand (FasL) on gastric epithelial cells in Helicobacter pylori gastritis; influence of $\mathrm{H}$. pylori eradication. Clin Exp Immunol 2000;119:464-71.

24. Gavrieli Y, Sherman Y, Ben Sasson SA. Identification of programmed cell death in situ via specific labeling of nuclear DNA fragmentation. J Cell Biol 1992;119:493-501.

25. Potten CS. The significance of spontaneous and induced apoptosis in the gastrointestinal tract of mice. Cancer Metastasis Rev 1992;11:179-95.

26. Wagner S, Beil W, Westermann J, Logan RP, Bock CT, Trautwein C, et al. Regulation of gastric epithelial cell growth by Helicobacter pylori: evidence for a major role of apoptosis. Gastroenterology 1997;113:1836-47.

27. Fan X, Gunasena H, Cheng Z, Espejo R, Crowe SE, Ernst PB, et al. Helicobacter pylori urease binds to class II MHC on gastric epithelial cells and induces their apoptosis. J Immunol 2000;165:1918-24.

28. Galmiche A, Rassow J, Doye A, Cagnol S, Chambard JC, Contamin S, et al. The $\mathrm{N}$-terminal $34 \mathrm{kDa}$ fragment of Helicobacter pylori vacuolating cytotoxin targets mitochondria and induces cytochrome c release. EMBO J 2000;19:6361-70.

29. El Zimaity HM, Graham DY, Genta RM, Lechago J. Sustained increase in gastric antral epithelial cell proliferation despite cure of Helicobacter pylori infection. Am J Gastroenterol 2000;95:930-5.

30. Genta RM, Rugge M. Gastric precancerous lesions: heading for an international consensus. Gut 1999;45(1 Suppl):I5-8. 
31. Hsiang YH, Wu HY, Liu LF. Proliferation-dependent regulation of DNA topoisomerase II in cultured human cells. Cancer Res 1988;48:3230-5.

32. Rugge M, Di Mario F, Cassaro M, Baffa R, Farinati F, Rubio J, Jr, Ninfo V. Pathology of the gastric antrum and body associated with Helicobacter pylori infection in nonulcerous patients: is the bacterium a promoter of intestinal metaplasia? Histopathology 1993;22:9-15.

33. Zhang P. The cell cycle and development: redundant roles of cell cycle regulators. Curr Opin Cell Biol 1999;11:655-62.

34. Sgambato A, Cittadini A, Faraglia B, Weinstein IB. Multiple functions of p27(Kip1) and its alterations in tumor cells: a review. J Cell Physiol 2000;183:18-27.

35. Mori M, Mimori K, Shiraishi T, Tanaka S, Ueo H, Sugimachi K, Akiyoshi T. p27 expression and gastric carcinoma. Nat Med 1997;3:593.

36. Tsihlias J, Kapusta L, Slingerland J. The prognostic significance of altered cyclin-dependent kinase inhibitors in human cancer. Annu Rev Med 1999;50:401-23.

37. Tsoli E, Gorgoulis VG, Zacharatos P, Kotsinas A, Mariatos G, Kastrinakis NG, et al. Low levels of p27 in association with deregulated $\mathrm{p} 53$-pRb protein status enhance tumor proliferation and chromosomal instability in non-small cell lung carcinomas. Mol Med 2001;7:418-29.

38. Zhang P, Wong C, DePinho RA, Harper JW, Elledge SJ. Cooperation between the Cdk inhibitors p27(KIP1) and p57(KIP2) in the control of tissue growth and development. Genes Dev 1998;12:3162-7.

39. Tian JQ, Quaroni A. Involvement of p21(WAF1/Cip1) and p27(Kip1) in intestinal epithelial cell differentiation. Am J Physiol 1999;276:C1245-58.

40. Troncone G, Vetrani A, de Rosa G, Gerbasio D, Palombini L. Cyclin dependent kinase inhibitor p27Kip1 expression in normal and neoplastic cervical epithelium. J Clin Pathol 1999;52:880-7.

41. Walsh S, Murphy M, Silverman M, Odze R, Antonioli D, Goldman $\mathrm{H}$, et al. p27 expression in inflammatory bowel disease-associated neoplasia. Further evidence of a unique molecular pathogenesis. Am J Pathol 1999;155:1511-8.

42. De Marzo AM, Meeker AK, Epstein JI, Coffey DS. Prostate stem cell compartments: expression of the cell cycle inhibitor p27Kip1 in normal, hyperplastic, and neoplastic cells. Am J Pathol 1998;153:911-9.

43. Syder AJ, Guruge JL, Li Q, Hu Y, Oleksiewicz CM, Lorenz RG, et al. Helicobacter pylori attaches to NeuAc alpha 2,3Gal beta 1,4 glycoconjugates produced in the stomach of transgenic mice lacking parietal cells. Mol Cell 1999;3:263-74.

44. Sommi P, Savio M, Stivala LA, Scotti C, Mignosi P, Prosperi E, et al. Helicobacter pylori releases a factor(s) inhibiting cell cycle progression of human gastric cell lines by affecting cyclin E/cdk2 kinase activity and Rb protein phosphorylation through enhanced p27(KIP1) protein expression. Exp Cell Res 2002;281:128-39.

45. Weiss H, Gutz HJ, Schroter J, Wildner GP. DNA distribution pattern in chronic gastritis. I. DNA ploidy and cell cycle distribution. Scand J Gastroenterol 1989;24:643-8.

46. Shirin H, Sordillo EM, Kolevska TK, Hibshoosh H, Kawabata $\mathrm{Y}$, Oh SH, et al. Chronic Helicobacter pylori infection induces an apoptosis-resistant phenotype associated with decreased expression of p27(kipl). Infect Immun 2000;68:5321-8.

47. Yu J, Leung WK, Ng EK, To KF, Ebert MP, Go MY, et al. Effect of Helicobacter pylori eradication on expression of cyclin D2 and p27 in gastric intestinal metaplasia. Aliment Pharmacol Ther 2001;15:1505-11. 